\title{
Meningkatkan kemandirian dan hasil belajar siswa melalui pengembangan Mobile Learning berbasis Android berbantuan Ispring Suite 9
}

\author{
Kiki Zilfia Auliatul Maurisa, Wening Patmi Rahayu* \\ Universitas Negeri Malang, Jl. Semarang No. 5 Malang, Jawa Timur, Indonesia \\ *Penulis korespondensi, Surel: wening.patmi.fe@um.ac.id
}

Paper received: 7-6-2021; revised: 21-6-2021; accepted: 28-6-2021

\begin{abstract}
Abstrak
Penelitian pengembangan mobile learning berbasis android berbantuan Ispring Suite 9 untuk meningkatkan kemandirian dan hasil belajar peserta didik dilatar belakangi oleh kurangnya sumber belajar dan inovasi media pembelajaran yang digunakan dalam pembelajaran daring selama masa pandemi Covid-19 di SMK Negeri 2 Kediri. Penelitian dan pengembangan ini bertujuan mengembangkan media pembelajaran mobile learning berbasis android berbantuan Ispring Suite 9 mata pelajaran Administrasi Umum untuk peserta didik kelas X OTKP di SMK Negeri 2 Kediri yang kemudian untuk diuji kelayakannya melalui validasi tiga ahli serta menguji pengaruh mobile learning tersebut dalam meningkatkan kemandirian dan hasil belajar peserta didik yang telah menggunakannya. Penelitian ini menggunakan model penelitian dan pengembangan (R\&D) teori dari Borg \& Gall yang dimodifikasi menjadi 8 langkah. Uji coba lapangan dilakukan pada kelas X OTKP 3 di SMK Negeri 2 Kediri dengan jumlah 36 peserta didik. Selain itu teknik analisis data yang digunakan yaitu teknik analisis data deskriptif persentase. Penelitian dan pengembangan ini adalah menghasilkan media pembelajaran mobile learning berbasis android berbantuan Ispring Suite 9 pada mata pelajaran Administrasi Umum yang bernama "Stemrling" (Study Mobile Learning). Berdasarkan hasil validasi oleh ahli materi dan ahli media mencapai persentase sebesar $97,5 \%$ dan $97,36 \%$, serta uji coba kelompok kecil mencapai 91,98\%. Sedangkan untuk hasil penyebaran angket kemandirian belajar pada saat uji coba lapangan, kelas eksperimen dan kelas kontrol masing-masing memperoleh skor sebesar $86 \%$ dan $69 \%$. Selain itu, untuk hasil pelaksanaan post-test hasil belajar pada saat uji coba lapangan, kelas eksperimen dan kelas kontrol masing-masing memperoleh skor 93\% dan 83\%. Berdasarkan hasil diatas dapat disimpulkan bahwa mobile learning yang dikembangkan layak digunakan dalam proses pembelajaran dan terbukti dapat meningkatkan kemandirian dan hasil belajar peserta didik. Saran yang diberikan untuk pengembangan produk selanjutnya adalah perlu dilakukan pengembangan pada kompetensi dasar lainnya serta dapat diunggah pada platform digital, seperti di playstore atau di iOS.
\end{abstract}

Kata kunci: penelitian dan pengembangan; media pembelajaran; mobile learning; android; ispring suite 9; kemandirian belajar; hasil belajar; administrasi umum

\section{Pendahuluan}

Secara definisi, pembelajaran telah mengalami perubahan, dari definisi pembelajaran tradisional, kemudian berkembang menjadi definisi pembelajaran transisi, dan yang terakhir adalah definisi pembelajaran secara modern. Secara modern, Pembelajaran didefinisikan sebagai suatu kegiatan menciptakan situasi dan kondisi dimana peserta didik dapat mengubah dirinya sendiri dari segi kemampuan, pola pikir, wawasan, sikap, kepribadian, motivasi, serta seluruh aspek kepribadian dalam dirinya menjadi lebih baik (Mulyadi et al., 2016). Melalui definisi pembelajaran tersebut dapat diketahui bahwa pembelajaran pada masa kini menuntut peserta didik untuk lebih aktif dan mandiri dalam belajar untuk mengembangkan potensi dan kompetensi yang dimilikinya. Dalam hal ini kemandirian belajar peserta didik berperan aktif untuk menciptakan kondisi tersebut. Mulyadi et al. (2016) menjelaskan bahwa kemandirian belajar adalah proses perencanaan, pemantauan dan evaluasi dalam aktivitas belajar yang 
dilandasi oleh keyakinan pada kemampuan diri sendiri dan komitmen pencapaian tujuan belajar atau tugas-tugas akademis sehingga tujuan belajar seperti penugasan, pengetahuan dan keterampilan dapat tercapai. Sejalan dengan Zimmerman (dalam Mulyadi et al., 2016) menjelaskan bahwa peserta didik yang memiliki kemandirian pada proses belajarnya mampu memulai dan mengarahkan usahanya untuk memperoleh pengetahuan serta keterampilan daripada harus bergantung kepada guru, orangtua atau agen pembelajaran lain. Peserta didik yang menerapkan kemandirian belajar akan memiliki inisiatif sendiri untuk mengevaluasi kemajuan dirinya yang berhubungan dengan tujuan yang telah mereka tetapkan dan akan menyesuaikan tingkah lakunya sesuai hasil evaluasi tersebut yang mana hal tersebut dapat meningkatkan hasil belajarnya.

Hasil belajar adalah kapabilitas yang dimiliki peserta didik setelah ia melakukan proses pembelajaran (Sudjana, 2010). Hasil belajar sebagai objek penilaian pada dasarnya adalah untuk menilai penguasaan peserta didik terhadap tujuan instruksional pembelajaran karena tujuan instruksional menggambarkan kemampuan peserta didik setelah memperoleh atau menyelesaikan pengalaman belajarnya (Sudjana, 2010). Dalam konteks pembelajaran, media pembelajaran turut mempengaruhi hasil belajar peserta didik. Ruth Lautfer (dalam Tafonao, 2018) mengemukakan bahwa media pembelajaran adalah salah satu alat bantu mengajar bagi guru untuk menyampaikan materi pengajaran, meningkatkan kreatifitas peserta didik dan meningkatkan perhatian peserta didik dalam proses pembelajaran. Dengan adanya media pembelajaran, peserta didik akan lebih termotivasi untuk belajar mandiri, mendorong peserta didik menulis, berbicara, dan berimajinasi. Senada dengan Jalinus and Ambiyar (2016) menjelaskan bahwa media pembelajaran merupakan perangkat lunak dan perangkat keras yang dapat dimanfaatkan untuk menyampaikan materi belajar kepada peserta didik yang dapat menstimulus perasaan, pikiran, minat dan perhatian dalam proses belajar sehingga lebih efektif. Media pembelajaran penting digunakan untuk memaksimalkan proses pembelajaran. Dengan menggunakan media pembelajaran, guru dapat memperkaya pengalaman belajar dan memberikan contoh lebih nyata kepada peserta didik.

Media pembelajaran pada era ini tidak terlepas dari teknologi informasi. Teknologi berperan sebagai alat yang dibutuhkan untuk menyampaikan materi pembelajaran dan memudahkan serta mendukung proses pembelajaran untuk meningkatkan kompetensi peserta didik pada kondisi normal maupun di masa pembelajaran daring. Perkembangan teknologi android baik yang dikemas dalam smartphone maupun aplikasi lain yang berbasis android dapat memberikan kemudahan bagi penggunanya (Muyaroah and Fajartia, 2017). Rifai et al. (2020) mengemukakan bahwa smartphone merupakan salah satu perangkat yang dapat dimanfaatkan sebagai media pembelajaran, karena mudah dibawa kemana-mana dan lebih efisien. Dalam bidang pendidikan, perkembangan teknologi ini dapat diterapkan dalam pembuatan media belajar peserta didik.

Mobile learning merupakan pembelajaran yang memanfaatkan perangkat teknologi komunikasi dan informasi sebagai media pembelajaran. Mobile learning juga dapat meningkatkan perhatian peserta didik terhadap materi pembelajaran sehingga proses pembelajaran terkesan lebih menarik (Martha et al., 2018). Sejalan dengan pendapat Sarrab et al. (dalam Martha et al., 2018) mobile learning memungkinkan untuk meningkatkan produktivitas peserta didik dengan membuat pengetahuan dan pembelajaran yang tersedia kapan saja dan dimana saja, yang memungkinkan peserta didik untuk berpartisipasi dalam kegiatan pembelajaran tanpa batas ruang dan waktu. Senada dengan penelitian tersebut 
Rahmat et al. (2019) juga menyebutkan pembelajaran mobile learning memiliki dampak positif bagi proses pembelajaran karena melalui mobile learning pembelajaran bisa dilakukan dalam jarak jauh. Oleh karena itu, penggunaan mobile learning dimasa pembelajaran daring sangat dibutuhkan untuk menunjang proses pembelajaran.

Salah satu aplikasi untuk membantu guru dalam memproduksi media pembelajaran mobile learning berbasis android adalah Ispring Suite 9 (Alfiyansah, 2016). Andi (2010) memaparkan bahwa power point merupakan salah satu aplikasi unggulan dalam paket Microsoft Office. Aplikasi ini secara khusus memiliki dan menyediakan semua kebutuhan dalam hal pembuatan slide presentasi. Beragam bentuk dan format presentasi dapat dibuat dengan visualisasi. Namun kini selain faktor penyajian presenter, tampilan slide mempunyai andil yang besar dalam sebuah presentasi. Kemasan file presentasi membentuk karakter dari penyaji dan materi yang disajikan. Nilai sebuah presentasi kini telah bergeser pada kualitas desain tampilan, kesesuaian konten, fitur efek animasi dan bisa dikolaborasikan dengan berbagai perantara atau plug in tambahan aplikasi, salah satunya yaitu dengan software Ispring Suite 9. Alfiyansah (2016) mengatakan bahwa Ispring merupakan salah satu tool yang mengubah file presentasi menjadi bentuk flash dan dapat dibuka di hampir setiap komputer, smartphone atau platform.

Beberapa penelitian sebelumnya yang juga relevan dengan topik tersebut adalah penelitian yang dilakukan oleh Sadikin and Hamidah (2020), Chung et al. (2019), Hendikawati et al. (2019), Huda et al. (2019), Rahmat et al. (2019), Alhafidz and Haryono (2018), Irawan and Rww (2018), Ngandhika et al. (2018), Tani and Ekawati (2017), Rahmawati and Mukminan (2017), Wijaya and Wibawa (2017), Briz-Ponce et al. (2016), Zheng et al. (2016), Martono and Nurhayati (2014). Berdasarkan beberapa penelitian tersebut dapat disimpulkan bahwa media pembelajaran mobile learning berbasis android berbantuan Ispring Suite 9 yang dikembangakan layak diimplementasikan dalam kegiatan pembelajaran di sekolah tingkat menengah kejuruan. media pembelajaran mobile learning tersebut juga mendapat respon yang sangat positif dari pengguna dan meningkatkan kemandirian dan hasil belajar peserta didik.

Sejauh ini, terbatasnya media pembelajaran mobile learning yang menjadi penunjang dalam proses pembelajaran daring membuat peserta didik tidak dapat belajar secara mandiri yang mana hal tersebut membuat hasil belajar peserta didik menurun. Disisi lain peserta didik dituntut mempelajari berbagai jenis-jenis administrasi, tugas kantor, personil administrasi, struktur organisasi, fungsi manajemen, macam-macam tata ruang kerja kantor, penataan kantor, dan komunikasi di tempat kerja. Pada kondisi pembelajaran daring seperti sekarang ini minimnya sumber belajar peserta didik dapat menghambat proses pembelajaran dan berdampak pada pencapaian belajar peserta didik. Sebagai solusi dari permasalahan tersebut, maka perlu diterapkan media pembelajaran mobile learning berbasis android sebagai media penunjang kegiatan pembelajaran peserta didik. 


\section{Metode}

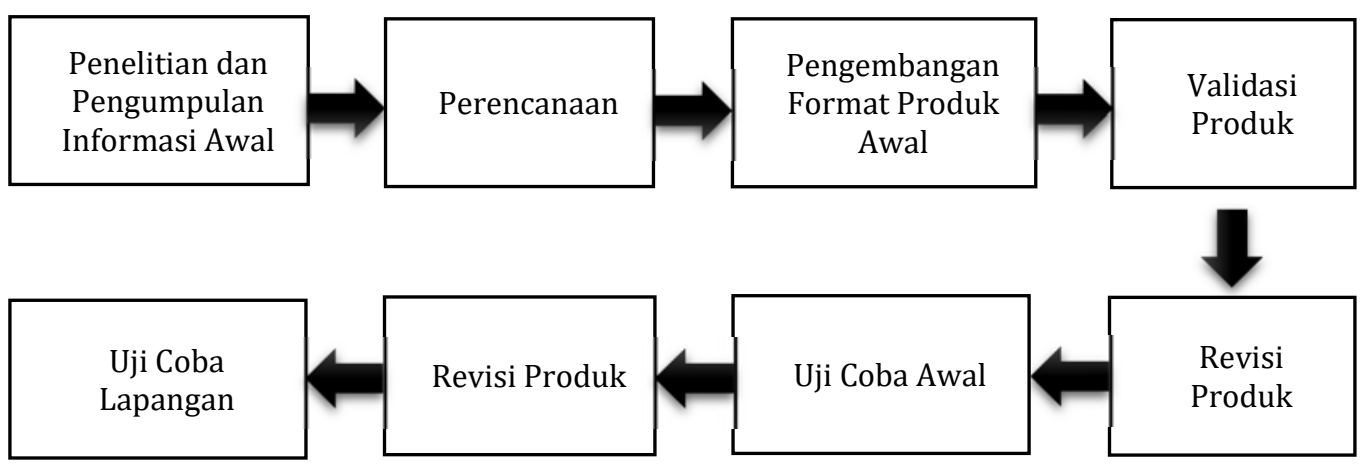

\section{Gambar 1. Langkah-langkah Penelitian dan Pengembangan}

Penelitian ini menggunakan model Research and Development Borg \& Gall yang dimodifikasi menjadi delapan langkah untuk menyederhanakan tahap-tahap sesuai dengan kebutuhan. Melalui delapan langkah tersebut peneliti dapat menghasilkan produk, mengetahui kelayakan produk, dan mengetahui perbedaan kemandirian dan hasil belajar peserta didik yang menggunakan produk dengan yang tidak menggunakan produk.

Langkah pertama, peneliti melakukan identifikasi masalah dengan cara wawancara secara tidak terstruktur dengan guru mata pelajaran Administrasi Umum di SMK Negeri 2 Kediri untuk mengetahui kebutuhan media pembelajaran di lapangan dengan didasarkan pada tuntutan saat ini. Langkah kedua, peneliti mulai merumuskan tujuan penelitian, subyek pengguna media pembelajaran, sampai dengan materi yang akan diterapkan dalam media pembelajaran. Langkah ketiga, peneliti membuat format produk awal atau rancangan media pembelajaran sesuai dengan indikator dan tujuan pembelajaran yang akan dicapai. Pada tahap ini peneliti menyatukan bahan dan realisasi desain. Langkah keempat, peneliti melibatkan 2 ahli validasi, yaitu validasi ahli materi dan validasi ahli media yang masing-masing telah mahir di bidangnya. Langkah kelima, peneliti melakukan revisi berdasarkan kritik dan saran, serta hasil validasi dari ahli materi dan media. Langkah keenam, peneliti melakukan uji coba awal pada kelompok kecil sejumlah 6 orang peserta didik kelas X OTKP dengan kemampuan heterogen. Langkah ketujuh, peneliti melakukan revisi berdasarkan hasil uji coba kelompok kecil. Langkah kedelapan, peneliti melakukan uji coba produk pada 36 peserta didik di kelas X OTKP 3 sebagai kelas eksperimen untuk mengukur kelayakan dan keefektifan produk yang dikembangakan.

Data yang dihasilkan pada penelitian dan pengembangan ini merupakan data kualitatif dan data kuantitatif. Data kualitatif berupa kritik dan saran dari validator ahli media, ahli materi, dan uji coba kelompok kecil. Sedangkan untuk data kuantitatif berupa perhitungan terhadap penilaian skor yang telah diberikan oleh ahli media, ahli materi, dan subjek uji coba melalui lembar angket validasi, angket uji coba, dan pelaksanaan post-test yang kemudian dianalisis menggunakan metode deskriptif persentase untuk mengetahui tingkat kelayakan dan keefektifan produk dalam meningkatkan kemandirian dan hasil belajar peserta didik. 


\section{Hasil dan Pembahasan}

Penelitian dan pengembangan ini menghasilkan produk berupa media pembelajaran mobile learning berbasis android berbantuan Ispring Suite 9 pada mata pelajaran Administrasi Umum kelas X OTKP yang diberi nama "Stemrling" (Study Mobile Learning). Media pembelajaran ini memuat materi mata pelajaran Administrasi Umum pada KD 3.9 Menerapkan Tata Ruang Kerja/Kantor (Office Layout) dan KD 4.9 Melakukan Penataan Tata Ruang Kerja/Kantor (Office Layout) serta KD 3.10 Menerapkan Komunikasi di Tempat Kerja dan KD 4.10 Melakukan Komunikasi di Tempat Kerja. Media pembelajaran yang dikembangan memiliki beberapa menu yakni 1) Menu KI/KD yang mencangkup Kompetensi Inti dan Kompetensi Dasar OTKP Administrasi Umum, 2) Menu Materi berisikan materi KD 3.9 Menerapkan Tata Ruang Kerja/Kantor (Office Layout) dan KD 3.10 Menerapkan Komunikasi di Tempat Kerja yang dapat dipelajari oleh peserta didik, 3) Menu Rangkuman yang berisikan rangkuman materi menerapkan tata ruang kerja/kantor (office layout) dan menerapkan komunikasi di tempat kerja, 4) Menu Video Pembelajaran berisikan video pembelajaran materi menerapkan tata ruang kerja/kantor (office layout) dan menerapkan komunikasi di tempat kerja, 5) Menu Absensi Siswa yang berisikan nama-nama peserta didik untuk melakukan kegiatan absensi, 6) Menu Evaluasi yaitu menu yang berisikan latihan soal setiap KD yang berupa latihan soal pilihan ganda dan true and false yang dilengkapi dengan menu hasil nilai peserta didik yang telah mengerjakan akan langsung keluar, 7) Menu Hubungi Guru yang berisikan whatsapp dan e-mail guru untuk membantu peserta didik jika memerlukan bantuan atau ada hal yang perlu ditanyakan kepada guru, 8) Menu Glosarium yaitu menu yang berisikan penjelasan dari istilah-istilah yang ada pada aplikasi Stemrling, 9) Menu Daftar Pustaka berisikan tentang berbagai sumber atau rujukan dari isi materi pembelajaran, 10) Menu Profil Pengembang yaitu berisikan tentang profil dan informasi pengembang aplikasi Stemrling, 11) Menu Petunjuk Penggunaan yang berisikan tata cara penggunaan media pembelajaran Stemrling. Media pembelajaran ini juga dapat dioperasikan secara offline untuk mengakses materi yang terdapat dalam aplikasi sehingga memudahkan peserta didik untuk mengoperasikan aplikasi Stemrling. Gambar 2 berikut ini merupakan preview dari halaman cover dan menu utama dalam Stemrling. 

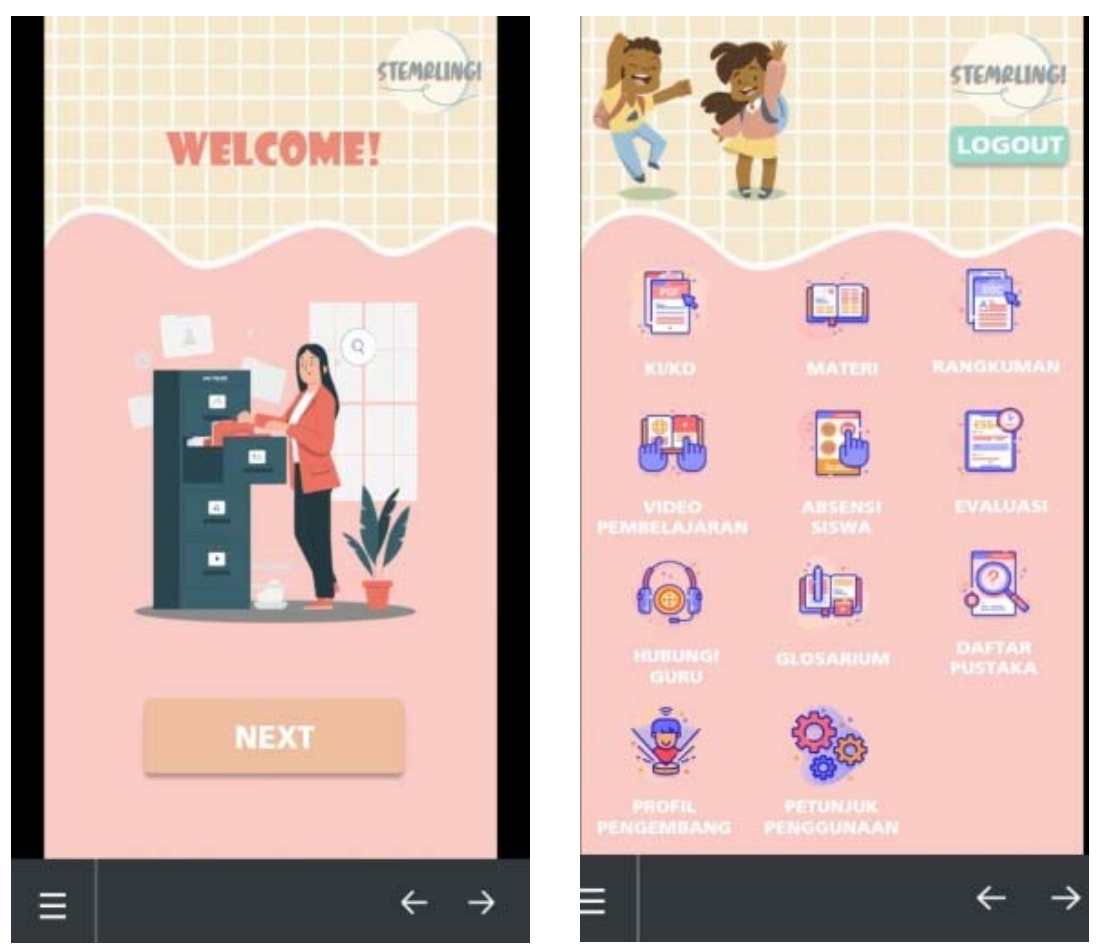

Gambar 2. Halaman Cover dan Menu Utama Stemrling

Hasil validasi media pembelajaran Stemrling oleh ahli materi, ahli media, dan uji coba kelompok kecil disajikan dalam Tabel 1 berikut ini:

Tabel 1. Data Hasil Validasi Keseluruhan

\begin{tabular}{llll}
\hline No & Validasi & Persentase & Kriteria Validitas \\
\hline 1. & Ahli Materi & $97,5 \%$ & Sangat Valid \\
2. & Ahli Media & $97,36 \%$ & Sangat Valid \\
3. & Uji Coba Kelompok Kecil & $91,98 \%$ & Sangat Valid \\
& Rata-rata & $95,61 \%$ & Sangat Valid \\
\hline
\end{tabular}

Table used by permission (CMaurisa, K.Z.A 2021. Data hasil validasi gabungan.

Berdasarkan Tabel 1, didapatkan hasil dari validasi gabungan memperoleh nilai 95,61\%, sehingga media pembelajaran mobile learning berbasis android yang dikembangkan dianggap sangat valid dan layak untuk digunakan, kualitas media dari segi materi, tampilan, dan kegunaan dianggap mampu untuk membantu peserta didik melakukan proses pembelajaran di kelas maupun di luar kelas. Selain itu, pemanfaatan media pembelajaran mobile learning ini sangat membantu guru karena akan meningkatkan kualitas proses pembelajaran dan juga membantu peserta didik untuk belajar mandiri. Media pembelajaran ini dapat dibuat dan dirancang sendiri oleh guru sesuai dengan kemampuan dan kebutuhan peserta didik (Rusman, 2017). Hal tersebut senada dengan penelitian yang dilakukan oleh (Sapitri and Bentri, 2020), (Hapidz et al., 2019), (Yumini and Rakhmawati, 2015), (Jatmiko et al., 2018) yang menyatakan bahwa layak atau tidaknya media pembelajaran yang dikembangkan dinilai dari hasil validasi oleh validator ahli materi, validator ahli media pembelajaran dan uji coba kelompok kecil. 
Media pembelajaran Stemrling menyediakan materi dengan video pembelajaran yang menarik, serta terdapat rangkuman dari penjelasan tersebut. Selain itu, media pembelajaran ini didesain secara menarik dan mudah digunakan sehingga peserta didik tidak merasa bosan saat menggunakannya. Lebih lanjut, peserta didik dapat mengakses media pembelajaran Stemrling ini tanpa menggunakan jaringan internet. Karena semua materi, rangkuman, serta evaluasi tersedia secara offline. Kecuali untuk video pembelajaran, hubungi guru, dan absensi siswa, peserta didik membutuhkan koneksi internet untuk mengaksesnya. Yang mana hal tersebut memudahkan peserta didik dan dapat membuat peserta didik termotivasi untuk mempelajarinya. Hal tersebut sejalan dengan penelitian yang dilakukan oleh Biswas et al. (2020) yang menyatakan bahwa dengan menggunakan mobile learning akan memotivasi peserta didik dalam belajar, dari motivasi inilah yang nantinya akan berubah jadi inisiatif peserta didik untuk terus belajar meskipun dalam kondisi yang berbeda.

Media pembelajaran Stemrling ini terbukti memberikan dampak sangat positif terhadap kemandirian belajar peserta didik. Hal ini ditunjukkan dengan adanya analisis data kemandirian belajar peserta didik meningkat secara signifikan. Tidak hanya peningkatan hasil kemandirian belajar peserta didik, media pembelajaran Stemrling ini juga mampu menjadi pengganti ketidakhadiran guru secara fisik dalam meningkatkan kemandirian peserta didik sehingga pembelajaran daring tetap berjalan secara efektif dan peserta didik tidak kehilangan pengalaman untuk belajar.

Tingkat kemandirian belajar peserta didik setelah menggunakan media pembelajaran Stemrling dianalisis menggunakan deskriptif persentase. Hasil persentase yang diperoleh kemudian diinterpretasikan berdasarkan Tabel 2 berikut:

Tabel 2. Standar Kriteria Kategorisasi Kemandirian Belajar Peserta Didik

\begin{tabular}{ll}
\hline Kriteria & Rumus Standar Kriteria \\
\hline Tinggi & $\mathrm{N} \geq \mathrm{p} 70$ \\
Sedang & $\mathrm{N} \geq \mathrm{p} 30-\mathrm{N}<\mathrm{p} 70$ \\
Rendah & $\mathrm{N}<\mathrm{p} 30$ \\
\hline
\end{tabular}

(Sumber: Ana and Achdiani, 2017)

Pada tahap uji coba lapangan, peserta didik diinstruksikan untuk mengisi kuesioner tingkat kemandirian belajar setelah melakukan kegiatan pembelajaran menggunakan media pembelajaran yang dikembangkan. Hasil analisis data dari kuesioner tersebut disajikan dalam Tabel 3 dan 4 berikut ini.

Tabel 3. Data Hasil Uji Kemandirian Belajar Peserta Didik Kelas Eksperimen

\begin{tabular}{ccccccccccccccccccccc}
\hline No. & \cline { 2 - 4 } & $\mathbf{1}$ & $\mathbf{2}$ & $\mathbf{3}$ & $\mathbf{4}$ & $\mathbf{5}$ & $\mathbf{6}$ & $\mathbf{7}$ & $\mathbf{8}$ & $\mathbf{9}$ & $\mathbf{1 0}$ & $\mathbf{1 1}$ & $\mathbf{1 2}$ & $\mathbf{1 3}$ & $\mathbf{1 4}$ & $\mathbf{1 5}$ & (f) & (n) & $\mathbf{1 0 0 \%}$ & $\begin{array}{c}\text { P } \\
(\mathbf{1 0 0} \%)\end{array}$ \\
\hline 1. & 4 & 4 & 4 & 4 & 4 & 4 & 4 & 4 & 4 & 4 & 4 & 4 & 4 & 4 & 4 & 60 & 60 & 100 & $100 \%$ \\
2. & 3 & 3 & 3 & 3 & 3 & 2 & 3 & 2 & 3 & 3 & 3 & 3 & 3 & 3 & 3 & 43 & 60 & 100 & $72 \%$ \\
3. & 4 & 4 & 3 & 4 & 4 & 3 & 3 & 4 & 4 & 3 & 4 & 3 & 4 & 4 & 4 & 55 & 60 & 100 & $92 \%$ \\
4. & 4 & 3 & 4 & 3 & 3 & 3 & 2 & 3 & 4 & 2 & 3 & 4 & 4 & 4 & 4 & 50 & 60 & 100 & $83 \%$ \\
5. & 3 & 3 & 3 & 3 & 3 & 2 & 3 & 3 & 3 & 3 & 3 & 2 & 2 & 4 & 3 & 43 & 60 & 100 & $72 \%$ \\
6. & 4 & 3 & 4 & 3 & 3 & 4 & 4 & 3 & 3 & 3 & 3 & 4 & 3 & 3 & 4 & 51 & 60 & 100 & $85 \%$ \\
7. & 3 & 3 & 4 & 3 & 4 & 3 & 3 & 3 & 4 & 3 & 4 & 3 & 3 & 4 & 3 & 50 & 60 & 100 & $83 \%$ \\
8. & 4 & 4 & 4 & 4 & 4 & 4 & 4 & 3 & 3 & 3 & 4 & 3 & 4 & 4 & 3 & 55 & 60 & 100 & $92 \%$
\end{tabular}




\begin{tabular}{|c|c|c|c|c|c|c|c|c|c|c|c|c|c|c|c|c|c|c|}
\hline \multirow{2}{*}{ No. } & \multicolumn{14}{|c|}{ Nomor Soal } & \multirow{2}{*}{ (f) } & \multirow{2}{*}{ (n) } & \multirow{2}{*}{$100 \%$} & \multirow{2}{*}{$\begin{array}{c}P \\
(100 \%) \\
\end{array}$} \\
\hline & 1 & 2 & 3 & 4 & 5 & 6 & 7 & 89 & $9 \quad 10$ & 11 & 12 & 13 & 14 & 15 & & & & \\
\hline 9. & 3 & 3 & 4 & 4 & 4 & 4 & 4 & $\begin{array}{ll}443 \\
\end{array}$ & 4 & 4 & 4 & 3 & 4 & 3 & 55 & 60 & 100 & $92 \%$ \\
\hline 10. & 4 & 4 & 4 & 3 & 4 & 4 & 3 & 44 & 4 & 4 & 4 & 4 & 4 & 4 & 58 & 60 & 100 & $97 \%$ \\
\hline 11. & 3 & 3 & 3 & 3 & 3 & 3 & 3 & 33 & 3 & 3 & 3 & 3 & 4 & 3 & 46 & 60 & 100 & $77 \%$ \\
\hline 12. & 4 & 4 & 3 & 4 & 3 & 3 & 4 & 43 & 4 & 4 & 4 & 3 & 4 & 4 & 55 & 60 & 100 & $92 \%$ \\
\hline 13. & 4 & 4 & 4 & 4 & 4 & 3 & 4 & 34 & 4 & 4 & 4 & 4 & 4 & 4 & 58 & 60 & 100 & $97 \%$ \\
\hline 14. & 4 & 4 & 3 & 3 & 4 & 3 & 4 & 32 & 2 & 2 & 4 & 4 & 3 & 4 & 49 & 60 & 100 & $82 \%$ \\
\hline 15. & 4 & 4 & 4 & 3 & 4 & 4 & 4 & $4 \quad 4$ & 4 & 3 & 4 & 4 & 4 & 4 & 58 & 60 & 100 & $97 \%$ \\
\hline 16. & 4 & 4 & 3 & 3 & 4 & 3 & 3 & 44 & 4 & 4 & 4 & 4 & 4 & 4 & 56 & 60 & 100 & $93 \%$ \\
\hline 17. & 4 & 4 & 4 & 4 & 4 & 2 & 4 & 33 & 2 & 2 & 2 & 4 & 4 & 4 & 50 & 60 & 100 & $83 \%$ \\
\hline 18. & 3 & 3 & 4 & 3 & 2 & 3 & 3 & 2 & 3 & 4 & 3 & 3 & 4 & 3 & 46 & 60 & 100 & $77 \%$ \\
\hline 19. & 3 & 3 & 4 & 3 & 3 & 4 & 3 & 34 & 2 & 3 & 3 & 3 & 4 & 4 & 49 & 60 & 100 & $82 \%$ \\
\hline 20. & 3 & 3 & 3 & 4 & 3 & 4 & 3 & 34 & 3 & 4 & 3 & 3 & 4 & 3 & 50 & 60 & 100 & $83 \%$ \\
\hline 21. & 4 & 4 & 4 & 3 & 4 & 4 & 4 & 43 & 4 & 3 & 4 & 3 & 4 & 4 & 56 & 60 & 100 & $93 \%$ \\
\hline 22. & 4 & 4 & 4 & 4 & 4 & 4 & 3 & 44 & 4 & 4 & 3 & 4 & 3 & 4 & 57 & 60 & 100 & $95 \%$ \\
\hline 23. & 4 & 4 & 3 & 4 & 4 & 3 & 4 & 34 & 3 & 3 & 4 & 4 & 4 & 4 & 55 & 60 & 100 & $92 \%$ \\
\hline 24. & 3 & 3 & 3 & 3 & 3 & 2 & 3 & 33 & 3 & 3 & 3 & 3 & 3 & 4 & 45 & 60 & 100 & $75 \%$ \\
\hline 25. & 2 & 3 & 3 & 4 & 4 & 3 & 4 & 34 & 3 & 1 & 4 & 4 & 3 & 4 & 49 & 60 & 100 & $82 \%$ \\
\hline 26. & 4 & 4 & 4 & 4 & 4 & 3 & 4 & $4 \quad 2$ & 2 & 2 & 3 & 4 & 4 & 4 & 52 & 60 & 100 & $87 \%$ \\
\hline 27. & 4 & 3 & 4 & 4 & 4 & 4 & 3 & 34 & 4 & 4 & 3 & 3 & 3 & 4 & 54 & 60 & 100 & $90 \%$ \\
\hline 28. & 4 & 4 & 4 & 3 & 4 & 4 & 4 & 34 & 4 & 4 & 3 & 4 & 4 & 3 & 56 & 60 & 100 & $93 \%$ \\
\hline 29. & 3 & 4 & 3 & 2 & 4 & 3 & 2 & 33 & 3 & 2 & 3 & 3 & 3 & 4 & 45 & 60 & 100 & $75 \%$ \\
\hline 30. & 4 & 3 & 4 & 3 & 4 & 3 & 3 & 33 & 4 & 3 & 3 & 4 & 4 & 4 & 52 & 60 & 100 & $87 \%$ \\
\hline 31. & 4 & 4 & 4 & 3 & 3 & 4 & 4 & 43 & 4 & 3 & 4 & 4 & 3 & 4 & 55 & 60 & 100 & $92 \%$ \\
\hline 32. & 3 & 3 & 3 & 3 & 3 & 2 & 4 & 32 & 2 & 1 & 2 & 3 & 4 & 4 & 42 & 60 & 100 & $70 \%$ \\
\hline 33. & 3 & 3 & 3 & 3 & 3 & 3 & 3 & 33 & 3 & 3 & 3 & 3 & 3 & 4 & 45 & 60 & 100 & $75 \%$ \\
\hline 34. & 4 & 4 & 4 & 3 & 4 & 4 & 3 & $4 \quad 4$ & 4 & 4 & 4 & 4 & 4 & 4 & 58 & 60 & 100 & $97 \%$ \\
\hline 35. & 4 & 4 & 4 & 4 & 4 & 4 & 4 & $4 \quad 4$ & 4 & 4 & 4 & 4 & 4 & 4 & 60 & 60 & 100 & $100 \%$ \\
\hline 36. & 3 & 2 & 3 & 3 & 3 & 2 & 2 & 22 & 22 & 3 & 3 & 3 & 3 & 3 & 39 & 60 & 100 & $65 \%$ \\
\hline & & & & & & & & IMLA & AH & & & & & & 1.857 & 2.160 & $100 \%$ & $86 \%$ \\
\hline
\end{tabular}

Table used by permission @Maurisa, K.Z.A, 2021. Data hasil uji kemandirian belajar peserta didik kelas eksperimen.

Tabel 4. Data Hasil Uji Kemandirian Belajar Peserta Didik Kelas Kontrol

\begin{tabular}{|c|c|c|c|c|c|c|c|c|c|c|c|c|c|c|c|c|c|c|c|}
\hline \multirow{2}{*}{ No. } & \multicolumn{15}{|c|}{ Nomor Soal } & \multirow{2}{*}{ (f) } & \multirow{2}{*}{ (n) } & \multirow{2}{*}{$100 \%$} & \multirow{2}{*}{$\begin{array}{c}P \\
(100 \%)\end{array}$} \\
\hline & 1 & 2 & 3 & 4 & 5 & 6 & 7 & 8 & 9 & 10 & 11 & 12 & 13 & 14 & 15 & & & & \\
\hline 1. & 3 & 3 & 2 & 2 & 3 & 3 & 2 & 2 & 2 & 3 & 3 & 3 & 3 & 2 & 2 & 38 & 60 & 100 & $63 \%$ \\
\hline 2. & 2 & 2 & 3 & 3 & 2 & 3 & 2 & 2 & 2 & 2 & 2 & 2 & 3 & 3 & 3 & 36 & 60 & 100 & $60 \%$ \\
\hline 3. & 3 & 3 & 2 & 2 & 3 & 4 & 2 & 2 & 3 & 3 & 2 & 2 & 2 & 3 & 2 & 38 & 60 & 100 & $63 \%$ \\
\hline 4. & 3 & 3 & 2 & 3 & 2 & 3 & 3 & 3 & 3 & 3 & 2 & 3 & 3 & 3 & 2 & 41 & 60 & 100 & $68 \%$ \\
\hline 5. & 3 & 2 & 2 & 4 & 2 & 2 & 2 & 2 & 3 & 2 & 3 & 3 & 2 & 3 & 4 & 39 & 60 & 100 & $65 \%$ \\
\hline 6. & 3 & 3 & 2 & 4 & 3 & 3 & 3 & 2 & 3 & 3 & 3 & 3 & 3 & 4 & 3 & 45 & 60 & 100 & $75 \%$ \\
\hline 7. & 3 & 2 & 2 & 2 & 3 & 3 & 3 & 2 & 4 & 3 & 3 & 3 & 3 & 2 & 3 & 41 & 60 & 100 & $68 \%$ \\
\hline 8. & 3 & 3 & 2 & 3 & 2 & 3 & 2 & 4 & 2 & 3 & 2 & 3 & 2 & 3 & 3 & 40 & 60 & 100 & $67 \%$ \\
\hline 9. & 2 & 3 & 3 & 3 & 3 & 2 & 1 & 1 & 2 & 2 & 2 & 2 & 3 & 3 & 2 & 34 & 60 & 100 & $57 \%$ \\
\hline 10. & 3 & 2 & 3 & 4 & 2 & 3 & 2 & 2 & 3 & 2 & 3 & 3 & 3 & 4 & 4 & 43 & 60 & 100 & $72 \%$ \\
\hline 11. & 3 & 2 & 2 & 4 & 2 & 2 & 2 & 2 & 3 & 2 & 3 & 2 & 2 & 4 & 4 & 39 & 60 & 100 & $65 \%$ \\
\hline 12. & 2 & 2 & 3 & 4 & 2 & 3 & 4 & 3 & 2 & 2 & 2 & 3 & 3 & 3 & 3 & 41 & 60 & 100 & $68 \%$ \\
\hline
\end{tabular}




\begin{tabular}{|c|c|c|c|c|c|c|c|c|c|c|c|c|c|c|c|c|c|c|c|}
\hline \multirow{2}{*}{ No. } & \multicolumn{15}{|c|}{ Nomor Soal } & \multirow{2}{*}{ (f) } & \multirow{2}{*}{ (n) } & \multirow{2}{*}{$100 \%$} & \multirow{2}{*}{$\begin{array}{c}P \\
(100 \%)\end{array}$} \\
\hline & 1 & 2 & 3 & 4 & 5 & 6 & 7 & 8 & \begin{tabular}{ll|}
9 & 1 \\
\end{tabular} & 10 & 11 & 12 & 13 & 14 & 15 & & & & \\
\hline 13. & 3 & 3 & 3 & 3 & 2 & 2 & 2 & 2 & 2 & 2 & 2 & 4 & 3 & 4 & 3 & 40 & 60 & 100 & $67 \%$ \\
\hline 14. & 3 & 3 & 3 & 2 & 3 & 2 & 2 & 3 & 2 & 2 & 2 & 2 & 3 & 3 & 2 & 37 & 60 & 100 & $62 \%$ \\
\hline 15. & 4 & 3 & 2 & 2 & 3 & 3 & 2 & 3 & 2 & 3 & 3 & 2 & 3 & 2 & 3 & 40 & 60 & 100 & $67 \%$ \\
\hline 16. & 3 & 2 & 2 & 4 & 2 & 2 & 2 & 2 & 2 & 2 & 3 & 2 & 3 & 3 & 3 & 37 & 60 & 100 & $62 \%$ \\
\hline 17. & 3 & 4 & 3 & 4 & 3 & 3 & 2 & 3 & 2 & 3 & 2 & 3 & 3 & 4 & 4 & 46 & 60 & 100 & $77 \%$ \\
\hline 18. & 3 & 2 & 3 & 4 & 2 & 3 & 2 & 2 & 3 & 2 & 3 & 2 & 3 & 2 & 4 & 40 & 60 & 100 & $67 \%$ \\
\hline 19. & 3 & 2 & 2 & 4 & 2 & 3 & 2 & 2 & 3 & 2 & 3 & 2 & 2 & 4 & 4 & 40 & 60 & 100 & $67 \%$ \\
\hline 20. & 3 & 3 & 2 & 4 & 2 & 3 & 2 & 2 & 4 & 3 & 3 & 3 & 2 & 4 & 4 & 44 & 60 & 100 & $73 \%$ \\
\hline 21. & 4 & 3 & 4 & 3 & 4 & 4 & 4 & 3 & 3 & 3 & 3 & 4 & 4 & 4 & 4 & 54 & 60 & 100 & $90 \%$ \\
\hline 22. & 3 & 2 & 2 & 4 & 2 & 2 & 2 & 2 & 3 & 2 & 4 & 2 & 3 & 4 & 4 & 41 & 60 & 100 & $68 \%$ \\
\hline 23. & 3 & 3 & 2 & 4 & 2 & 3 & 2 & 2 & 3 & 3 & 3 & 2 & 3 & 4 & 4 & 43 & 60 & 100 & $72 \%$ \\
\hline 24. & 3 & 2 & 2 & 3 & 2 & 2 & 2 & 2 & 2 & 2 & 3 & 3 & 2 & 3 & 4 & 37 & 60 & 100 & $62 \%$ \\
\hline 25. & 3 & 2 & 2 & 4 & 2 & 3 & 2 & 2 & 2 & 2 & 3 & 2 & 3 & 3 & 4 & 39 & 60 & 100 & $65 \%$ \\
\hline 26. & 4 & 4 & 4 & 3 & 3 & 3 & 2 & 3 & 3 & 3 & 4 & 3 & 3 & 3 & 4 & 49 & 60 & 100 & $82 \%$ \\
\hline 27. & 3 & 3 & 3 & 3 & 2 & 3 & 2 & 2 & 3 & 2 & 3 & 2 & 3 & 3 & 2 & 39 & 60 & 100 & $65 \%$ \\
\hline 28. & 4 & 3 & 3 & 4 & 2 & 3 & 2 & 3 & 3 & 3 & 3 & 2 & 3 & 3 & 3 & 44 & 60 & 100 & $73 \%$ \\
\hline 29. & 3 & 3 & 3 & 4 & 3 & 3 & 2 & 3 & 3 & 2 & 2 & 2 & 3 & 4 & 4 & 44 & 60 & 100 & $73 \%$ \\
\hline 30. & 3 & 2 & 3 & 4 & 2 & 2 & 2 & 2 & 3 & 2 & 3 & 2 & 2 & 4 & 4 & 40 & 60 & 100 & $67 \%$ \\
\hline 31. & 3 & 2 & 3 & 4 & 3 & 3 & 2 & 2 & 3 & 2 & 3 & 2 & 3 & 2 & 3 & 40 & 60 & 100 & $67 \%$ \\
\hline 32. & 4 & 3 & 3 & 4 & 3 & 2 & 2 & 4 & 4 & 4 & 2 & 4 & 4 & 4 & 4 & 51 & 60 & 100 & $85 \%$ \\
\hline 33. & 2 & 3 & 4 & 3 & 2 & 2 & 2 & 3 & 3 & 2 & 3 & 3 & 2 & 3 & 3 & 40 & 60 & 100 & $67 \%$ \\
\hline 34. & 3 & 3 & 2 & 2 & 2 & 3 & 2 & 4 & 3 & 2 & 3 & 2 & 3 & 4 & 4 & 42 & 60 & 100 & $70 \%$ \\
\hline 35. & 3 & 3 & 3 & 4 & 2 & 3 & 2 & 2 & 3 & 2 & 2 & 3 & 3 & 3 & 4 & 42 & 60 & 100 & $70 \%$ \\
\hline 36. & 3 & 2 & 3 & 4 & 2 & 3 & 2 & 2 & 3 & 2 & 3 & 2 & 2 & 3 & 3 & 39 & 60 & 100 & $65 \%$ \\
\hline & & & & & & & & ML & $\mathrm{AH}$ & & & & & & & 1.483 & 2.160 & $100 \%$ & $69 \%$ \\
\hline
\end{tabular}

Table used by permission (CMaurisa, K.Z.A, 2021. Data hasil uji kemandirian belajar peserta didik kelas kontrol.

Berdasarkan Tabel 3 dan 4 diatas dapat disimpulkan bahwa hasil analisis data kemandirian belajar dari kuesioner kelas eksperimen atau kelas X OTKP 3 didapatkan hasil persentase sebesar $86 \%$, sehingga dapat dikategorikan bahwa kemandirian belajar peserta didik kelas X OTKP 3 yang menggunakan media pembelajaran Stemrling dinyatakan "Tinggi". Sedangkan kelas kontrol atau kelas X OTKP 2 mendapatkan hasil persentase sebesar $69 \%$. Artinya terdapat perbedaan sebesar $17 \%$ antara rata-rata kemandirian belajar peserta didik yang menggunakan Stemrling dan yang tidak menggunakan Stemrling. Dengan demikian dapat disimpulkan bahwa penggunaan media pembelajaran Stemrling sangat layak digunakan untuk meningkatkan kemandirian belajar peserta didik.

Media pembelajaran Stemrling (Study Mobile Learning) ini terbukti memberikan dampak sangat positif terhadap hasil belajar peserta didik. Hal ini ditunjukkan dengan adanya analisis data hasil belajar peserta didik meningkat secara signifikan. Hal tersebut relevan dengan penelitian yang dilakukan oleh sejumlah peneliti diantaranya Damayanti, (2018) yang menunjukan bahwa dengan penggunaan media berbasis android dapat meningkatkan hasil belajar. Senada dengan Himmah and Martini (2017) yang menyatakan bahwa hasil belajar peserta didik yang menggunakan media pembelajaran berbasis android meningkat dibandingkan peserta didik yang tidak menggunakan media pembelajaran tersebut. Hal ini diperkuat dengan penelitian yang dilakukan oleh Putra et al. (2017) yang menjelaskan bahwa 
media pembelajaran berbasis android dapat meningkatkan hasil belajar peserta didik secara signifikan, memiliki pengaruh positif dalam pembelajaran, dan terbukti memiliki perbedaan yang signifikan antara rata-rata hasil belajar kelas eksperimen dan kelas kontrol.

Pada tahap uji coba lapangan, peserta didik diinstruksikan untuk mengerjakan soal posttest setelah melakukan kegiatan pembelajaran menggunakan media pembelajaran yang dikembangkan untuk mengetahui hasil belajar peserta didik. Hasil analisis data hasil belajar tersebut disajikan dalam Tabel 5 berikut ini.

Tabel 5. Data Hasil Post-test Kelas Eksperimen dan Kelas Kontrol

\begin{tabular}{|c|c|c|c|c|}
\hline \multirow{2}{*}{$\begin{array}{c}\text { No. Absen } \\
\text { Peserta Didik }\end{array}$} & \multicolumn{3}{|c|}{ Kelas Eksperimen } & \multirow{2}{*}{$\begin{array}{c}\text { Kelas Kontrol } \\
\text { Ketercapaian KKM (75) }\end{array}$} \\
\hline & Nilai & Ketercapaian KKM (75) & Nilai & \\
\hline 1. & 100 & $>\mathrm{KKM}$ & 92 & $>\mathrm{KKM}$ \\
\hline 2. & 96 & $>\mathrm{KKM}$ & 72 & $<\mathrm{KKM}$ \\
\hline 3. & 100 & $>\mathrm{KKM}$ & 72 & $<\mathrm{KKM}$ \\
\hline 4. & 80 & $>\mathrm{KKM}$ & 84 & $>\mathrm{KKM}$ \\
\hline 5. & 88 & $>\mathrm{KKM}$ & 88 & $>\mathrm{KKM}$ \\
\hline 6. & 96 & $>\mathrm{KKM}$ & 68 & $<\mathrm{KKM}$ \\
\hline 7. & 92 & $>\mathrm{KKM}$ & 84 & $>\mathrm{KKM}$ \\
\hline 8. & 96 & $>\mathrm{KKM}$ & 92 & $>\mathrm{KKM}$ \\
\hline 9. & 96 & $>\mathrm{KKM}$ & 80 & $>\mathrm{KKM}$ \\
\hline 10. & 88 & $>\mathrm{KKM}$ & 76 & $>\mathrm{KKM}$ \\
\hline 11. & 100 & $>\mathrm{KKM}$ & 96 & $>\mathrm{KKM}$ \\
\hline 12. & 92 & $>\mathrm{KKM}$ & 72 & $<\mathrm{KKM}$ \\
\hline 13. & 88 & $>\mathrm{KKM}$ & 78 & $>\mathrm{KKM}$ \\
\hline 14. & 92 & $>\mathrm{KKM}$ & 88 & $>\mathrm{KKM}$ \\
\hline 15. & 92 & $>\mathrm{KKM}$ & 96 & $>\mathrm{KKM}$ \\
\hline 16. & 96 & $>\mathrm{KKM}$ & 84 & $>\mathrm{KKM}$ \\
\hline 17. & 100 & $>$ KKM & 92 & $>$ KKM \\
\hline 18. & 92 & $>$ KKM & 72 & $<\mathrm{KKM}$ \\
\hline 19. & 100 & $>\mathrm{KKM}$ & 84 & $>\mathrm{KKM}$ \\
\hline 20. & 96 & $>$ KKM & 84 & $>\mathrm{KKM}$ \\
\hline 21. & 92 & $>\mathrm{KKM}$ & 100 & $>\mathrm{KKM}$ \\
\hline 22. & 96 & $>\mathrm{KKM}$ & 84 & $>\mathrm{KKM}$ \\
\hline 23. & 84 & $>$ KKM & 84 & $>\mathrm{KKM}$ \\
\hline 24. & 100 & $>\mathrm{KKM}$ & 72 & $<\mathrm{KKM}$ \\
\hline 25. & 100 & $>\mathrm{KKM}$ & 80 & $>\mathrm{KKM}$ \\
\hline 26. & 92 & $>\mathrm{KKM}$ & 88 & $>\mathrm{KKM}$ \\
\hline 27. & 76 & $>$ KKM & 72 & $<\mathrm{KKM}$ \\
\hline 28. & 92 & $>\mathrm{KKM}$ & 80 & $>\mathrm{KKM}$ \\
\hline 29. & 96 & $>\mathrm{KKM}$ & 84 & $>\mathrm{KKM}$ \\
\hline 30. & 88 & $>$ KKM & 84 & $>\mathrm{KKM}$ \\
\hline 31. & 88 & $>$ KKM & 76 & $>\mathrm{KKM}$ \\
\hline 32. & 100 & $>$ KKM & 92 & $>\mathrm{KKM}$ \\
\hline 33. & 92 & $>$ KKM & 100 & $>\mathrm{KKM}$ \\
\hline 34. & 92 & $>$ KKM & 88 & $>\mathrm{KKM}$ \\
\hline 35. & 92 & $>\mathrm{KKM}$ & 76 & $>\mathrm{KKM}$ \\
\hline
\end{tabular}


Jurnal Ekonomi, Bisnis dan Pendidikan, 1(6), 2021, 546-558

\begin{tabular}{ccccc}
\hline No. Absen & \multicolumn{2}{c}{ Kelas Eksperimen } & Kelas Kontrol \\
\cline { 2 - 5 } Peserta Didik & Nilai & Ketercapaian KKM (75) & Nilai & Ketercapaian KKM (75) \\
\hline 36. & 96 & $>$ KKM & 64 & $<$ KKM \\
Rata-rata & 93 & $100 \%$ & 83 & $78 \%$ \\
\hline
\end{tabular}

Table used by permission (C)aurisa, K.Z.A, 2021. Data hasil uji hasil belajar peserta didik.

Berdasarkan pemaparan hasil perhitungan post-test secara manual menunjukkan ratarata hasil belajar peserta didik kelas eksperimen adalah 93 dan ketercapaian terhadap KKM mencapai $100 \%$ atau semua peserta didik kelas eksperimen memiliki nilai diatas KKM. Sedangkan rata-rata hasil belajar peserta didik kelas kontrol adalah 83 dan ketercapaian terhadap KKM mencapai 78\% atau terdapat 8 peserta didik yang memiliki nilai dibawah KKM. Hal ini menunjukkan bahwa rata-rata hasil belajar kelas eksperimen lebih tinggi daripada kelas kontrol. Artinya terdapat perbedaan sebesar $10 \%$ antara rata-rata hasil belajar peserta didik yang menggunakan Stemrling dan yang tidak menggunakan Stemrling. Berdasarkan hal ini dapat disimpulkan bahwa penelitian dan pengembangan Study Mobile Learning (Stemrling) dikatakan berhasil sebab mampu mencapai ketuntasan klasikal kelas terhadap hasil belajar peserta didik yakni $100 \%$.

\section{Simpulan}

Penelitian ini menghasilkan media pembelajaran berbasis android yang bernama "Stemrling" (Study Mobile Learning) pada mata pelajaran Administrasi Umum kelas X OTKP yang terdiri dari $2 \mathrm{KD}$ untuk semester genap. Media pembelajaran Stemrling dapat diunduh dan diinstal secara gratis melalui http://bit.ly/DownloadStemrling.

Hasil validasi dari dua ahli, yakni ahli materi dan ahli media memperoleh nilai dengan kategori "Sangat Layak", sehingga media pembelajaran Stemrling layak diimplementasikan pada kegiatan pembelajaran. Terdapat perbedaan kemandirian belajar peserta didik antara pengguna media pembelajaran Stemrling dengan yang tidak menggunakan media pembelajaran Stemrling, ditinjau dari rata-rata kemandirian belajar peserta didik dimana kelas eksperimen memperoleh rata-rata lebih tinggi dibandingkan dengan kelas kontrol. Selain itu, terdapat perbedaan hasil belajar peserta didik antara pengguna media pembelajaran Stemrling dengan yang tidak menggunakan media pembelajaran Stemrling, ditinjau dari ratarata hasil belajar peserta didik dimana kelas eksperimen memperoleh rata-rata lebih tinggi dibandingkan dengan kelas kontrol.

Media pembelajaran Stemrling hanya dapat diakses oleh pengguna smartphone android, sehingga diharapkan agar dapat dikembangkan menggunakan sistem operasi lain seperti iOS dan aspek penilaian tidak hanya pada ranah kognitif melainkan juga psikomotorik dan afektif, selain itu juga penting untuk lebih mengembangkan pada pengolahan data hasil evaluasi agar langsung terekap dalam satu file tabulasi nilai. Selanjutnya, media pembelajaran Stemrling ini dikembangkan khusus untuk digunakan pada mata pelajaran Administrasi Umum kelas X OTKP yang terbatas hanya $2 \mathrm{KD}$, sehingga diharapkan adanya pengembangan media pembelajaran pada KD-KD yang lain. Lebih lanjut, menu video pembelajaran harus diakses secara online karena terhubung langsung dengan Youtube, sehingga dapat dikembangkan lagi agar saat melihat video bisa langsung di dalam aplikasi. Begitu pula dengan menu absensi siswa karena terhubung dengan google formulir dan menu hubungi guru karena langsung terhubung dengan aplikasi whatsapp dan e-mail. 


\section{Daftar Rujukan}

Alfiyansah, R. (2016). Penggunaan Media Pembelajaran ISpring Presenter Untuk Meningkatkan Motivasi Belajar dan Hasil Belajar Pada Mata Kuliah Keperawatan Dasar Nutrisi. Jurnal Ilmu Pendidikan, 14 (2), 363-369. DOI: 10.17509/pedagogia.v14i2.3886.

Alhafidz, M. R. L., \& Haryono, A. (2018). Pengembangan Mobile Learning Berbasis Android Sebagai Media Pembelajaran Ekonomi. Jurnal Pendidikan Ekonomi, 11 (7), 118¹24. DOI: 10.17977/UM014v11i22018p0107.

Ana, A., \& Achdiani, Y. (2017). Penerapan Self Regulated Learning Berbasis Internet Untuk Meningkatkan Kemandirian Belajar Mahasiswa. Innovation of Vicational Technology Education, 11 (1), 15־22. DOI: https: 10.17509/invotec.v11i1.4835.

Andi. (2010). Microsoft power point 2010. Yogyakarta: CV. Andi Offset.

Biswas, B., Roy, S. K., \& Roy, F. (2020). Students Perception of Mobile Learning During COVID-19 In Bangladesh: University Student Perspective. Aquademia, 4 (2), 19. DOI: 10.29333/aquademia/8443.

Briz-Ponce, L., Juanes-Méndez, J. A., García-Peñalvo, F. J., \& Pereira, A. (2016). Effects of Mobile Learning in Medical Education: A Counterfactual Evaluation. Journal of Medical System, 40 (6), 136. DOI: 10.1007/s10916-016-0487-4.

Chung, C. J., Hwang, G. J., \& Lai, C. L. (2019). A Review of Experimental Mobile Learning Research In 2010-2016 Based On The Activity Theory Framework. Computers \& Education, 129, 1'13. DOI: 10.1016/j.compedu.2018.10.010.

Damayanti, E. (2018). Efektifitas Penggunaan Media Ispring Suite 8 Terhadap Hasil Belajar Sejarah Kelas X SMAN 5 Pontianak. Jurnal Pendidikan dan Pembelajaran Khatulistiwa, 7(9).

Hapidz, R. A., Sumardi, K., \& Komaro, M. (2019). Desain dan Pembuatan Media Pembelajaran Mobile Learning Pada Mata Pelajaran Sistem dan Instalasi Tata Udara. Journal of Mechanical Engineering Education, 6 (1), 71779. DOI: 10.17509/Jmee.V6i1.18245.

Hendikawati, P., Zahid, M. Z., \& Arifudin, R. (2019). Android Based Computer Assisted Instruction Development as a Learning Resource for Supporting Self-Regulated Learning. International Journal of Instruction, 12 (3), 389-404. DOI: 10.29333/iji.2019.12324a.

Himmah, F., \& Martini, M. (2017). Pengembangan Multimedia Interaktif Menggunakan Ispring Suite 8 Pada Sub Materi Zat Aditif Untuk Meningkatkan Hasil Belajar Siswa SMP Kelas VIII. Pensa E-Jurnal: Pendidikan Sains, 5 (2), 7382. https://jurnalmahasiswa.unesa.ac.id/index.

Huda, M. N., Mulyono, M., Rosyida, I., \& Wardono, W. (2019). Kemandirian Belajar Berbantuan Mobile Learning. Jurusan Matematika, In PRISMA, Prosiding Seminar Nasional Matematika 2, 798-806. https://journal.unnes.ac.id/sju/index.php/prisma/.

Irawan, C., \& Rww, E. T. D. (2018). Developing Instructional Media Mobile Learning Based Android To Improve Learning Outcomes. Jurnal Pendidikan Bisnis dan Manajemen, 4 (3), 117-124. DOI: 10.17977/um003v4i32018p117.

Jalinus, N., \& Ambiyar, (2016). Media \& Sumber Pembelajaran. Jakarta: Prenamedia Group.

Jatmiko, B. B., Sugiyarto, K. H., \& Ikhsan, J. (2018). Developing ChemonDro Application on Redox Concepts to Improve Self-Regulated Learning of Students. Journal Physics: Conference Series, 1097, 1¹0. DOI: 10.1088/1742-6596/1097/1/012055.

Martha, Z. D., Adi, E. P., \& Soepriyanto, Y. (2018). Ebook Berbasis Mobile Learning. Jurnal Kajian Teknologi Pendidikan, 1 (2), 6. http://journal2.um.ac.id/index.php/jktp/article/view/3705/2775.

Martono, K. T., \& Nurhayati, O. D. (2014). Implementation of Android Based Mobile Learning Application As A Flexible Learning. International Journal of Computer Science Issues, 11 (3), 168¹74.

Mulyadi, S., Basuki, M. H., \& Rahardjo, W. (2016). Psikologi Pendidikan Dengan Pendekatan Teori-Teori Baru dalam Psikologi. Jakarta: PT RajaGrafindo Persada.

Muyaroah, S., \& Fajartia, M. (2017). Pengembangan Media Pembelajaran Berbasis Android dengan menggunakan Aplikasi Adobe Flash CS 6 pada Mata Pelajaran Biologi. Innovative Journal of Curriculum and Educational Technology, 6 (2), 79²83. DOI: 10.15294/IJCET.V6I2.19336.

Ngandhika, E. P., Rustiana, E.R., \& Pramono, H. (2018). Development of Android-Based Rhythmic Activity Learning Media on Physical Education in High School. Journal of Physical Education and Sports, 7 (2), 106¹12. DOI: 10.15294/jpes.v7i2.23612. 
Putra, K. W. B., Wirawan, I. M. A., \& Pradnyana, G. A. (2017). Pengembangan E-Modul Berbasis Model Pembelajaran Discovery Learning Pada Mata Pelajaran "Sistem Komputer" Untuk Siswa Kelas X Multimedia SMK Negeri 3 Singaraja 10. Jurnal Pendidikan Teknologi Dan Kejuruan, 14 (1), 4049. DOI: 10.23887/jptk-undiksha.v14i1.9880.

Rahmat, R. F., Mursyida, L., Rizal, F., Krismadinata, K., \& Yunus, Y. (2019). Pengembangan Media Pembelajaran Berbasis Mobile Learning Pada Mata Pelajaran Simulasi Digital. Jurnal Inovasi Teknologi Pendidikan, 6 (2), 116־1126. DOI: 10.21831/jitp.v6i2.27414.

Rahmawati, E. M., \& Mukminan. (2017). Pengembangang M-Learning Untuk Mendukung Kemandirian dan Hasil Belajar Mata Pelajaran Geografi. Jurnal Inovasi Teknologi Pendidikan, 4 (2), 157¹66. DOI: 10.21831/jitp.v4i2.12726.

Rifai, A., Sulton, \& Sulthoni. (2020). Pengembangan Media Mobile Learning Sebagai Pendukung Sumber Belajar Biologi Siswa SMA. Jurnal Kajian Teknologi Pendidikan, 3 (1), 10¹7. DOI: 10.17977/um038v3i12019p010.

Rusman. (2017). Belajar \& Pembelajaran Berorientasi Standar Proses Pendidikan. PT Kharisma Putra Utama.

Sadikin, A., \& Hamidah, A. (2020). Pembelajaran Daring di Tengah Wabah Covid-19. BIODIK, 6 (2), 109¹19. DOI: $10.22437 /$ bio.v6i2.9759.

Sapitri, D., \& Bentri, A. (2020). Pengembangan Media Pembelajaran Berbasis Aplikasi Articulate Storyline Pada Mata Pelajaran Ekonomi Kelas X. Inovation Technology Education, 2 (01), 8. DOI: 10.24036/Inovtech.V2i01.115.

Sudjana, N. (2010). Penilaian Hasil Proses Belajar Mengajar. Bandung: PT Remaja Rosdakarya.

Tafonao, T. (2018). Peranan Media Pembelajaran Dalam Meningkatkan Minat Belajar Mahasiswa. Jurnal Komunikasi Pendidikan, 2 (2), 103¹14. DOI: 10.32585/jkp.v2i2.113.

Tani, S., \& Ekawati, E. Y. (2017). Peningkatan Kemandirian Belajar Peserta Didik pada Materi Teori Kinetik Gas Melalui Penerapan Media Pembelajaran Interaktif Berbasis iSpring Suite 8. Jurnal Materi dan Pembelajaran Fisika, 7 (2), 13־16. DOI: 10.20961/jmpf.v7i2.31454.

Wijaya, A. Y. P., \& Wibawa, S. C. (2017). Pengembangan Media Pembelajaran Jaringan Komputer Berbasis Android Untuk Meningkatkan Hasil Belajar Siswa Di SMK Antartika Surabaya. Jurnal Information Technology and Education, 1 (2), 49־53. https://jurnalmahasiswa.unesa.ac.id/index.

Yumini, S., \& Rakhmawati, L. (2015). Pengembangan Media Pembelajaran Interaktif Berbasis Articulate Storyline Pada Mata Diklat Teknik Elektronika Dasar di SMK Negeri 1 Jetis Mojokerto. Jurnal Pendidikan Teknik Elektro, 04 (03), 845־849.

Zheng, L., Li, X., \& Chen, F. (2016). Effects of Mobile Self-Regulated Learning Approach On Students' Learning Achievements and Self-Regulated Learning Skills. Innovations in Education and Teaching International, 19. DOI: $10.1080 / 14703297.2016 .1259080$. 